\begin{tabular}{lll}
\hline Volume 5 & Number 6 & 1 JUNE 2020 \\
\hline
\end{tabular}

ROBERT CHAMPAGNE, RACHEL FORSYTH, WILLIAM MCCARTY, IAN NUNNELEY, ALLISON VANDERKOLK

\title{
SICK OF IT: HOW CORONAVIRUS PLAGUED A CASE STUDY PROJECT ${ }^{1}$
}

When you do not seek or need approval, you are at your most powerful. - Caroline Myss

Will McCarty, a senior in USF's EMBA program, was following Florida's recent "stay-at-home" order. He heard a message ping in the "Team Five" group chat. The chat read "Team, I will not be able to get approval to publish our team case. I am sorry".

This approval was required for Team Five to proceed with their Business Problems Analysis course's final assignment. For this assignment, the team was tasked to author and publish a case study detailing a complex real-world business decision. Ideally, the case study would focus on one of the team members' employer organizations. Dr. Gill had presented the class with two options for the assignment: 1.) Fine tune a case study topic that was initiated in a previous course, with the goal of academic publication 2.) Teams unable to garner publication consent could start over with a new case on a new topic.

The teammate's message was troubling; the first submission date for this assignment was looming. Team Five hoped that their case topic would receive publication approval. Because the team did not receive the necessary consent, they knew that they had to select a new case study topic.

McCarty and the team were in a difficult position only exacerbated by the Coronavirus pandemic. The virus had recently caused severe, widespread, and unprecedented global disruption. The team knew it would be nearly impossible to find an alternative company that would have the bandwidth to participate in developing a new case on such short notice. Arranging in person meetings or interviews was not feasible. Most, if not all, organizations were focused on business continuity plans related to the pandemic. McCarty typed up a text to his group, "Hear me out...can we write a case about how we can't find a case?" The team was intrigued, and McCarty offered to pitch the case to Dr. Gill the next day. As Dr. Gill's house phone rang, McCarty felt nervous - the team was running out of options. What would the team do if Dr. Gill did not accept the team's proposal?

\footnotetext{
${ }^{1}$ Copyright $(0) 2020$, Robert Champagne, Rachel Forsyth, William McCarty, Ian Nunneley, Allison Vanderkolk. This case was prepared for the purpose of class discussion, and not to illustrate the effective or ineffective handling of an administrative situation. Names and some information have been disguised. Permission is granted to copy and distribute this case for non-commercial purposes, in both printed and electronic formats. This template is based on a 2012 template originally developed for the Journal of IT Education: Discussion Cases.
} 


\section{The Program, the Course, and the Assignment}

As the team reflected on their conundrum, each team member took a step back and considered how they had ended up in this situation.

\section{USF EMBA Program}

The University of South Florida's Executive MBA program was designed for talented leaders looking to advance their careers by transitioning from Senior Management to the Executive level. Students enrolled in the program typically had 10+ years of management-level work experience and the program's mission was to challenge and revitalize these students so that they would be better prepared to take the next step in their careers. ${ }^{2}$ When the program's students introduced their unique career experiences and perspectives in a classroom setting, they enriched and augmented one another's learning experiences. Much of the USF EMBA program was driven by professors who lead collaborative discussions focused on real world case discussions - and this Business Problems Analysis capstone course was no exception.

All five of Team Five's team members had made the decision to enroll in USF's EMBA program as an investment in their own career ambitions. Team Five had a diverse portfolio of career experience, and each team member aspired to better their professional knowledge, skill sets, and professional network. The members of the team had been assigned to Team Five at the beginning of the senior year of the program. They had developed a bond as they migrated through the different program courses as a cohesive unit. At the beginning of that senior year (Fall of 2019), Team Five had completed the EMBA program's Integrated Business Solutions course. In that course, Team Five was first introduced to business case studies and "the business case discussion method". While in the Integrated Business Solutions course, the instructor had first alerted the class that they would have the opportunity to refine the cases that they had initiated in his course during their upcoming Business Problems Analysis course. The desired outcome of the continuation of the case topic and corresponding finetuning was academic publication. As 5 exited from their Integrated Business Solutions course, they were operating under the premise that the case study and topic that they had commenced for that course would receive the necessary publication consent needed to continue the project.

\section{MAN 6930: Business Problems Analysis}

In Spring 2020, Will McCarty and Team Five began their capstone Business Problems Analysis course. The conceptual "capstone" term drew illustrative parallels to a capstone; the final component added to a building or structure in order to signify the completion of its construction. Correspondingly, a capstone course/senior thesis served as the culminating and integrative experience of an educational program. ${ }^{3}$ This was no different for USF's EMBA program. Business Problems Analysis was the last course of the program. The USF EMBA program's materials noted that its Business Problems Analysis course offered an integrative approach to decision-making that would demand students to combine the cutting-edge concepts, principles and skills learned in the separate disciplines previously covered in the program. Case analysis and experiential methods were this course's primary vehicles for learning. Each team was required to develop, write and present a discussion case - generated from interviews with executives at companies in the Tampa Bay Area. Those cases deemed worthy would be put forward for possible publication in the Muma Case Review. ${ }^{4}$

The course was instructed by Professor Grandon Gill. Dr. Gill's research focus was the transdisciplinary study known as Informing Science, a field that focused on the synthesis of research informed by many different disciplines. Dr. Gill's research in those areas was published in many journals, including Informing Science, Decision Sciences Journal of Innovative Education, the Journal of Information 
Systems Education, eLearn, and Journal of IT Education, and MIS Quarterly -- the MIS discipline's leading journal. Dr. Gill earned a DBA and an MBA from Harvard Business School and a bachelor's degree from Harvard College. ${ }^{5}$ While enrolled in HBS's MBA and DBA programs, Dr. Gill quickly discovered that he thoroughly enjoyed and had a special kinship not only with the case method - but what the process delivered. It was Dr. Gill who was largely responsible for weaving the case study method into the fabric of the USF EMBA program.

\section{The Case Study Project}

Dr. Gill assigned the continuation of the case study project at the beginning of his Business Problem Solving course. Students were expecting the final EMBA capstone course assignment, as it had been prefaced in their previous Integrated Business Solutions course. At the initiation of the assignment, Dr. Gill presented teams with the options to either primarily revise their previous case study with the goal of submitting the case for publication or to secondarily develop a new case study. The teams had two months between deciding to take a chance on the previous case or start from scratch to the final case submission. Dr. Gill estimated 30 to 40 hours of preparation time for the assignment. This assignment was worth $50 \%$ of their capstone course grade. It was also worth noting that the two options required slightly different submission processes. If a team opted to use an existing case, they were required to submit publication approval, respond to an initial instructor review of their case draft, conduct a peer review, and then their final draft for Muma Case Review (MCR) publication review. Developing a new case would require submitting an introductory first page with a corresponding outline that detailed different sections and the sections' intent to the case, followed by a case draft, revisions based on peer review, and submission of the final draft. Exhibit 1 contains the syllabus for the course that discusses the assignment in more detail.

As discussed above, Dr. Gill had developed an affinity for the case study method and what it provided to its participants while at Harvard. Dr. Gill was passionate about the learning experience and corresponding benefits the method extended to students. Dr. Gill leveraged these case studies heavily in his courses. The case method was hinged to the artifact that was a discussion case study. Disparate to typical "case studies" that appeared frequently in textbooks to present a real world example, or the business cases that appeared on corporate web sites to illustrate the successful use of a product or service, discussion cases provided a detailed description of a real-world business, organizational or personal situation for which one or more decisions must be made. It was in the meticulous, purposeful, and diligent analysis of these decisions that were detailed in a case where a participant's judgment was required. The decision-oriented focus of the case was imperative. The discussion case would stop at the point where the decision should have been made. The participants in the case discussion then examined the situation from the perspective of central figures in the case - referred to as the case protagonists - and attempted to come up with the most sensible decision. In most of these situations, there was no right or wrong decision. Rather, there were some decisions that made sense, and many more that probably did not. The goal of analyzing the case study was to come up with at least one sensible course of action, and to eliminate as many bad choices as possible.

\section{Academic Journals and the Publication Process}

As the team thought about ways to address the situation that they were in, they also thought back to what Dr. Gill had spoken about in class about the merits of the publication component of the project. 


\section{Publication in Muma Case Review}

One of the primary objectives of Dr. Gill's final case study assignment was to submit the study to USF's Muma Case Review (MCR) journal with the intent of peer review followed by publication. Dr. Gill found it beneficial to expose students to the process of publication review for several reasons. For students interested in continuing their education from a master's into a doctoral program, it allowed them to become better prepared for that journal publication process which would be fundamental in their doctoral program studies. For students not interested in pursuing a doctorate degree, it still allowed their case to go through a peer reviewal process that allowed them to gather valuable feedback on their writing style, as well as their ability to efficiently and effectively convey thoughts and ideas. Furthermore, it provided students with insight to the process of having a case study reviewed and published in an academic journal - which was a new learning concept that the students would not typically have experienced previously. Exhibits 2 and 3 provide more detail around the purpose and history of the Muma Case Review.

\section{Academic Publishing Industry Background}

Contributions to academic publishing (also referred to as scholarly publishing) typically included books or articles. Those articles were published and distributed through the channel that was academic journals. To give the reader some context to the size of the industry, as of 2014, it was estimated that there were over 28,000 different active peer reviewed academic journals publishing articles. ${ }^{7}$ There were certain clues that could help one identify academic publication types from other publication channels. First, the authors who submitted articles or books to academic journals were generally associated with research universities or other types of research units. Second, the authors who worked with academic journals were also not often directly compensated by the academic journals for their contributions. Although, some authors did receive secondary compensation for their cases through career promotion or industry prestige. Third, when an author attempted to submit a case or article to an academic journal, those contributions were subjected to a peer review process. As part of the peer review process, the academic journal editor (or a member of the journal's staff) selected researchers familiar with the cases topic to review the submission and vet it for both quality and accuracy. This peer review process could have multiple timeconsuming cycles of iteration, but it helped the reader ensure that the articles published by the journal met the journal's expected quality standards. Finally, the "success" of an academic case or article was typically benchmarked by the industry ranking of the journal that published the work, and also by the frequency with which the article was cited by other researchers post-publication. ${ }^{8}$ Several factors were used to rank academic journals by industry (business, science, humanities, etc.) and those factors included the number of documents posted, the number of references included in the journal's published articles, the number of times the journal's publications were cited, and a unique measure of the journal's impact, influence, or prestige. That final metric was calculated by expressing the average weighted number of citations received in the selected year by the documents published in the journal in the three previous years. ${ }^{9}$

At the time that this case was written, there was certain criticism associated with the Academic Journal industry. Power was mostly concentrated by the top 5 publishers, and this concentration of power enabled these publishers to essentially control subscription fees for the entire industry. ${ }^{10}$ The research and time that went into writing and producing articles was not free. It was usually funded by universities, other research institutes, or the government. These universities were required to pay for access to the research that they were funding. Taxpayers also did not always have free access to the research that they were funding. 
There were three primary stakeholder bases operating within the academic journal industry. The first were the writers and editors of the articles themselves. The second were the academic journals who vetted, published, and distributed the articles. The third were the universities that purchased the journals for student and researcher reference purposes. ${ }^{11}$ As a general rule, Academic Journals operated on a for profit basis. The global academic industry generated over \$25.2 Billion in revenue in 2015 and North America accounted for $60 \%$ of this revenue. For a standard magazine, the majority of the costs came from creating, writing, and editing content. Academic Journals did not bear these costs; authors typically contributed their cases and articles for free and editing was completed via the free peer review process briefly discussed above. The purchase or access price associated with these publications has been on an increasing trend, since 1985 the price of an academic journal had risen $215 \%$. The highest priced journals were located in the STEM field. ${ }^{12}$ Some academic journals began to give authors, wishing that their academic contributions could be accessed by readers for free, the option to pay the journal "article processing" charges. An "open access" academic journal was a journal that provided readers with free access to their published content. These academic journals still charged universities and libraries to access and distribute their publications. This practice could result in academic publishers generating revenue both from the authors as well as the universities and other research institutes.

For background on why academic publication was so frequently associated with the faculty of research universities or institutes, there were two incentives for university faculty to create content for academic journals. First, academic journal publication was a norm of the profession. These norms strongly encouraged the research institute's faculty to produce and publish research. The second was tenure, and the role of credentialism strongly encouraged publishing articles in academic journals for credit. Many universities required that faculty members seeking promotion or tenure had to both "produce" and "consume" peer reviewed journal articles in scholarly publications. The intent of Dr. Gill's Business Problems Analysis course's final case study assignment fell outside of either of these two incentives. Dr. Gill simply wanted to expose his students to the benefits resulting from their cases going through the peer review and academic journal publishing process. This process required more engagement of the decisionmaking process than producing an academic paper that presented research or a thesis. It required immersion in the culture of the company and its decision-making executives, and a thorough understanding of the environment and constraints under which they were operating. A rigorous checklist of features and an engaging narrative were required for a compelling discussion case worthy of publication.

\section{Publication Consent}

The Muma Case Review (MCR) was an open access online outlet for academic case studies and articles. All MCR cases were typically published as soon as they had completed the journal's initial submission, corresponding peer review, and final formatting processes. As a result of this, it was imperative that case writers begin engaging with and discussing publication approval with the appropriate publication approvers from the inception of their project.

Dr. Gill's previous experiences had shown that many companies could be initially hesitant to the concept of having a case that focused on an internal organizational challenge published. In order for the students to overcome this potential initial uncertainty to publication, it was vital that the students get in front of the precariousness by having a conversation with the appropriate publication approver. During that discussion, it would be important to detail the candid pros and cons associated with publication of a case study of this nature. While allowing a case study focusing on a difficult business decision within an 
organization to be published did tip the reader that the company was not impervious to arduous challenges or obstacles, it delivered several benefits as well:

- Enhance and participate in the educational process: When a company allowed a case to be written about a difficult decision impacting them, they became an active participant in enhancing the educational process. While most executives complained that business schools were too divorced from the real world, those who participated in a case study could take pride in the fact that they were doing something to help address the problem.

- Relationship building: While collaborating on a case study, it provided the participants with the opportunity to establish or reinforce relationships with the case writer and the case writer's institution. Companies would frequently develop strong, and often enduring, relationships with the individuals who wrote the case. Those relationships could prove very valuable for companies looking to hire talented students or needing advice on some problem that involved research.

- Honest assessment: In allowing a case study to be authored and published, it provided the participatory company with a lens to how they were perceived by the outside world. Because the case writer needed to set the stage by describing the industry and the company, the case study painted a picture of the company as viewed by outsiders.

- A different perspective: Participating in a case often helped clarify the issues associated with a particular decision. Because a case writer's main objective was to gather information relating to a particular decision, the process of deciding what factors were relevant to a decision was often more systematic than it would have been under normal circumstances. In addition, any insights, information or expertise that the case writer possessed with respect to the decision was always available to the company. ${ }^{13}$

Exhibit 4 contains more information that Dr. Gill provided to organizations who were uncertain on whether they should participate in the case study and provided clearer guidelines on the participation process.

Dr. Gill's past experiences had also shown that students who engaged with publication approvers at the very beginning of the project and kept them continuously involved in reference to the status of the case details and corresponding progress had a much stronger likelihood of gaining the necessary approval, compared to those who first approached the publication approver at the end of the project with the completed work. In engaging with publication approvers at the onset of the project, the approver became more familiar and comfortable with the case topic, the business case method, and the goals and benefits of the exercise as the project matured - and thus were more likely to grant the publication approval necessary for the end product to come to published fruition.

Following the professor's guidance, Team Five engaged with the appropriate publication approvers at the beginning of the project. Unfortunately, the initiation of this project coincided with the onset of the Coronavirus pandemic in the United States. The persons who would have provided ultimate approval consent quickly realized that business considerations around the Coronavirus would demand their complete and undivided attention, and they would not be able to engage with Team Five as they worked through the development of the case, nor would they have the attention to escalate the "final" product for publication consent reviews by the appropriate internal departments. The publication approvers were sincerely apologetic when they communicated the inability to proceed with publication approval to Team Five. Team Five, understanding that these were unprecedented times of complete uncertainty, empathized with the company's inability to proceed with their project. 


\section{Alternative Project Options}

In looking at alternative paths forward, McCarty and Team Five reflected on other business challenges impacting the organizations that they worked for that they had started to analyze for previous course assignments. The team had previously worked on an assignment covering turnover issues at one of the member's companies, and the development of a new product at another member's company. The case covering the turnover issues was well researched and reached conclusions that were helpful to the company itself, but the company would not allow this case study to be published. That company operated in a highly specialized and an extremely young industry with very low barriers to entry. The main barrier to entry was lack of industry knowledge which could be obtained fairly quickly through the proper research. It was feared that the paper contained enough industry and company information so that an individual or company could use this information and potentially enter the market as a competitor. The second case involved the development of a new product to enhance the company's product portfolio as well as meeting the needs of an underdeveloped market. The case focused on the marketing strategy for that product's introduction and penetration into the market. Even when excluding financial information about the product, the case contained enough information that a competitor would have a roadmap for this company's strategy. The product being developed was unique to the market and was a product that customers needed and were actively seeking. If competitors were to have this information they would be able to enter this market and potentially undercut the original product that was in development. The team conceded that they were in a dire position - a position muddled by the introduction of the Coronavirus and its corresponding challenges.

\section{Coronavirus}

At the time of writing this case, the global Coronavirus pandemic was very much ongoing. The outbreak forced a shutdown of the American economy resulting in severe complications for writing a new case. Companies were focused on keeping their organizations running to the best of their abilities. They did not have the bandwidth to engage with Team Five and participate in a case study. In addition, the members of the team each dealt with the effects of the pandemic at their prospective jobs.

The outbreak was first discovered in Wuhan, China in December 2019. ${ }^{14}$ The World Health Organization declared it to be an outbreak on January 30, 2020 and a pandemic on March 11, 2020. As of April 16, 2020 , Reuters was reporting that there were over 646,000 cases with approximately 31,000 deaths in the US alone. The first known case of coronavirus in the United States was discovered in Washington state on January 20, 2020. The initial response from the federal government was to declare a national health emergency on January 31, 2020 and to restrict travel from China.

The virus itself was believed to be spread through close contact and respiratory droplets which were produced when people coughed or sneezed. It was thought that an individual could also contract the virus by touching a contaminated surface and then touching his or her face. The virus was most contagious when a person was symptomatic, but it also appeared to be spread by individuals who were asymptomatic. The time from exposure to symptoms ranged from three to 14 days. Common symptoms included fever, cough, shortness of breath, and strangely, complete loss of taste or smell. Complications could include pneumonia and acute respiratory distress syndrome. Most individuals with the virus could recover without any medical attention required. High risks groups required hospitalization, and individuals over 65 and those with immune system conditions were considered as high risk. ${ }^{18}$ 
Beginning March 15th, many businesses began to reduce their hours or completely close in order to reduce the spread of the virus. At this time the federal government recommended a shutdown of 15 days to prevent the spread. California enacted a complete lockdown. Residents were not allowed to leave homes except for essential purchases. New York, Connecticut, and New Jersey reduced gatherings to 50 people or less. In addition, they closed gyms, casinos and restaurants were limited to takeout only. Shortly following, other states such as Texas and Florida closed beaches, restaurants, bars, and any business where 10 or more people would gather. Businesses that were not forced to close by the government had greatly reduced the number of people who were required to come into the office. Many businesses required employees to begin working from home.

The Tampa Bay area was affected by the pandemic as well. On April 16, 2020 Reuters reported that there were 873 confirmed cases of the virus in Hillsborough County, including 18 deaths. ${ }^{15}$ It was likely that more individuals had the virus, but due to a national lack of supply of test kits it was difficult to gather accurate statistics. On April 2nd, Florida Governor Ron DeSantis issued a statewide "stay-at-home order". The order required all residents to stay at home 24 hours a day, 7 days a week except for access to services deemed "essential". These specific circumstances included going to purchase food, going to work at a business deemed essential, taking pets outside, and exercise. The guidelines recommend staying 6 feet apart from any other individual when leaving the home for accepted circumstances. ${ }^{16}$ Exhibit 5 contains Governor DeSantis's executive order covering the mandate. At the time of case writing it was unclear when this stay-at-home order would be lifted. The University of South Florida transitioned all classes to online formats beginning March $11^{\text {th }} .{ }^{17}$

The members of the team were affected in many different ways. One team member's company was fully shut down with all employees being furloughed. Another team member had an employee test positive for coronavirus and spent the majority of her time handling the situation. All members of the team were preparing for the possibility of loss of employment or the possibility of dealing with an active case of the virus at their workplace.

Almost every business globally and locally was affected in some way by the pandemic. It forced businesses to reconsider their business models, cut expenses, furlough or layoff employees, and some to cease operating completely. Exhibit 6 further details how the global economy was impacted by the coronavirus. Will McCarty and Team Five quickly recognized that it was unlikely that a local business would have the bandwidth to collaborate with an EMBA team to develop a case study for a school assignment. In addition, the team was unable to meet in person or meet in person with any business leaders. To develop a discussion case, there needed to be a considerable amount of interaction between a business and the team developing the case. The team conceded that they needed to be creative in how to potentially proceed in completing this final assignment that was required in order for them to graduate from the USF EMBA program.

\section{The Options}

McCarty and the team decided to hop on an ad hoc virtual meeting to discuss how they could proceed. The team was certainly aware that time was of the essence, as the deadlines for the project were rapidly approaching. Several options were discussed on that call, and the following were the options that the team viewed as most attainable coming out of that call.

Option 1: Proceed in writing a new case around a new topic (the second assignment option that had been presented by Dr. Gill), with the understanding that the case was unlikely to receive publication consent due to the state of affairs at the time. The team understood that publication for course option 2 was not 
mandatory, but the team felt as though they would miss out on the beneficial aspects of the publication process that the professor wished for them to experience.

Option 2: Highly fictionalize a case that the team had previously worked on, to the point that any information gained would not help potential competitors or reveal confidential company information. If the team proceeded with this option they would be able to spend time refining the case rather than writing a brand new case. The team would also have the opportunity to publish a case. The team had some concerns that a case so highly fictionalized to pass consideration for it to be published would mean that the case was now a distorted fiction versus a real business case. They worried that this fictionalization would dilute the lessons to be learned by the reader.

Option 3: Craft a new case from public sources. The team thought if the case was solely based on information gleaned from previously published material, the case itself would not require additional publication consent. While the team considered this option, they also wondered if they could find a case topic that they found personally interesting enough to build a case around. The team also wondered whether they would be able to gain the appropriate amount of internal company and protagonist perspective based on the limited information that was listed in the published information.

Option 4: Mislead Dr. Gill into thinking that they had received publication approval for their initial case topic and proceed under false pretenses until the assignment had been graded and final grades submitted. They could claim immediately prior to publication that the company had withdrawn their permission. The team had some ethical implications to weigh if they wanted to proceed with this option. While it was unlikely that Dr. Gill would determine he had been misled, the team recognized that they didn't want to conclude their entire USF EMBA program with a dishonest act.

Option 5: Finally, Will McCarty and the team thought about whether there might be an opportunity for an additional imaginative option that they might not have considered previously...

As McCarty and the team sat back and reflected on their options, they wondered how best to proceed. 


\section{References}

${ }^{2}$ Executive MBA: Take your Career to a Whole New Level . (2020). Executive MBA: Take your Career to a Whole New Level . Retrieved from

https://www.usf.edu/business/documents/graduate/emba/brochure.pd

${ }^{3}$ Ford, M. P. (2002). Beyond the modern university: toward a constructive postmodern university. Place of publication not identified: Information Age Publishing.

${ }^{4}$ College of Business / Graduate / EMBA / Coursework. (n.d.). Retrieved April 12, 2020, from https://www.usf.edu/business/graduate/emba/coursework.aspx

${ }^{5}$ College of Business / Contacts / Grandon Gill. (n.d.). Retrieved April 12, 2020, from https://www.usf.edu/business/contacts/gill-grandon.aspx

${ }^{6}$ Gill, G. (2016). WRITING A MUMA CASE REVIEW CASE. Muma Case Review. Retrieved from https://www.mumacasereview.org/

${ }^{7}$ Boon, S. (2017, January 7). 21 st Century Science Overload. Retrieved April 12, 2020, from http://blog.cdnsciencepub.com/21st-century-science-overload/

${ }^{8}$ Gill, G. (2016). A NOTE ON SCHOLARLY OPEN ACCESS PUBLISHING. Muma Case Review, 0(2). Retrieved from https://www.mumacasereview.org/

${ }^{9}$ (n.d.). Retrieved April 12, 2020, from https://www.scimagojr.com/journalrank.php?area=1400

${ }^{10}$ It's time to stand up to the academic publishing industry ...." 26 Feb. 2018, https://www.universityaffairs.ca/opinion/in-my-opinion/time-stand-academic-publishing-industry/. Accessed 30 Mar. 2020.

${ }^{11} \mathrm{http}: / /$ southernlibrarianship.icaap.org/content/v09n03/mcguigan_g01.html

${ }^{12}$ Market Power in the Academic Publishing Industry."

https://are.berkeley.edu/ sberto/mktpower_academic.pdf. Accessed 30 Mar. 2020.

${ }^{13}$ Gill, G. (n.d.). Why Should I Participate in a Case Study: Answers to 10 frequently asked questions.

${ }^{14}$ A Timeline of the Coronavirus Pandemic - The New York Times."

https://www.nytimes.com/article/coronavirus-timeline.html. Accessed 30 Mar. 2020.

${ }^{15}$ Hart, S. (2020, April 15). The novel coronavirus in the U.S. Retrieved April 16, 2020, from https://graphics.reuters.com/HEALTH-CORONAVIRUS-USA/0100B5K8423/index.html

${ }^{16}$ Clark, D. (2020, April 2). Florida governor issues stay-at-home order after weeks of resistance.

Retrieved April 12, 2020, from https://www.nbcnews.com/politics/politics-news/florida-governor-issuesstay-home-order-after-weeks-resistance-n1174146

17 "Update to the USF Community (3/11)." 11 Mar. 2020, https://www.usf.edu/coronavirus/updates/0311-update-usf-community.aspx. Accessed 30 Mar. 2020. 
18 "If you have been exposed to the Coronavirus" 27 April 2020, Retrieved from:

https://www.health.harvard.edu/diseases-and-conditions/if-youve-been-exposed-to-the-coronavirus 


\section{Biographies}

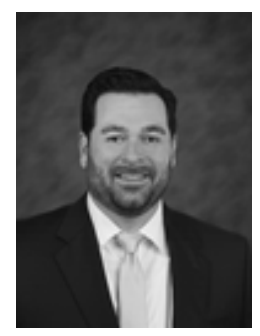

Robert Champagne is an Executive MBA student at the University of South Florida. He earned his BA from Boston University. He is Vice President, Pharmacy Benefit Relations at Envolve Pharmacy Solutions, a subsidiary of Centene Corporation. He has more than 20 years of experience working in Managed Care and Pharmacy, serving in leadership roles for more than a decade. Bob was previously employed by CVS Health and PharMerica Corporation.

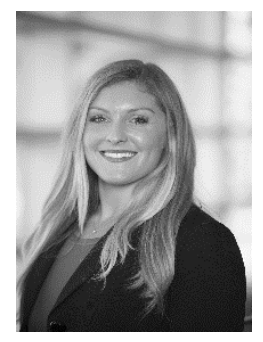

Allison VanderKolk is an Executive MBA student at the University of South Florida. She earned her BS in Engineering with honors from Michigan State University. She is an Operations Manager at Nestlé Waters North America in Zephyrhills, FL. With experience in science and research in food and beverage and medical product design, Allison focuses on continuous improvement in manufacturing within operations, engineering and technical departments.

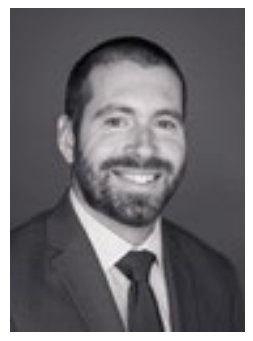

Ian Nunneley is enrolled in the Executive MBA program at The University of South Florida. He barely earned a BS in Business from Troy University. Currently he is the Training Manager for Knighted Gaming.

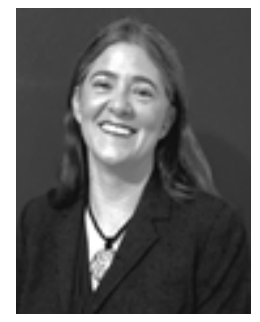

Rachel Forsyth is currently enrolled in the Executive MBA program at The University of South Florida. She earned a Bachelor of Science in Mechanical Engineering Technology from The University of North Texas where she has been honored as a Distinguished Alumni. Rachel is currently a General Manager for Pierce Manufacturing, a Division of Oshkosh. She has over 20 years of experience in operations and engineering leadership.

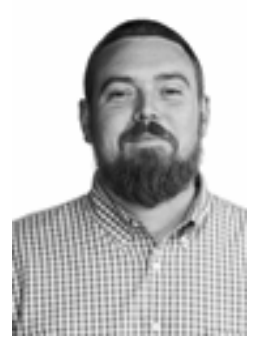

Will McCarty is a Project Manager with Invisors LLC. The company is a certified Workday Services Partner focused on large enterprise Workday software integrations. Prior to his current position, McCarty worked for a small startup, Bongo International, that was acquired by FedEx. As part of the merger, he helped drive the transition to the new FedEx OpCo of FedEx Cross Border. It was an experience that provided the knowledge and understanding of the politics and processes of a small tech startup compared to a global corporation. McCarty earned a bachelor's degree in marketing from USF and was a University Honors graduate. 


\section{Exhibit 1: USF MAN 6930 Course Syllabus}

\section{MAN 6930: Business Problems Analysis}

\begin{tabular}{|c|c|c|c|}
\hline \multicolumn{4}{|c|}{$\begin{array}{l}\text { Dr. T. Grandon Gill } \\
\text { grandon@usf.edu }\end{array}$} \\
\hline Instructor: & T. Grandon Gill & E-Mail: & grandon@usf.edu \\
\hline Term: & Spring 2020 & Dates: & $3 / 7 / 20-5 / 1 / 20$ \\
\hline $\begin{array}{l}\text { Delivery } \\
\text { Method: }\end{array}$ & Classroom & $\begin{array}{l}\text { Location \& } \\
\text { Time: }\end{array}$ & $\begin{array}{l}\text { BSN } 231 \\
\text { EMBA residencies }\end{array}$ \\
\hline $\begin{array}{l}\text { Course } \\
\text { Prerequisites: }\end{array}$ & \multicolumn{3}{|l|}{ None } \\
\hline $\begin{array}{l}\text { Intended } \\
\text { Audience }\end{array}$ & \multicolumn{3}{|l|}{ Executive MBA students } \\
\hline
\end{tabular}

\section{Case Study Project}

Because you developed cases in teams this summer, the course will offer two options.

Option 1: Taking an Existing Case through Publication

The goal of this option is to get an existing case published by the end of the semester. Groups taking this option must meet certain prerequisites. Specifically:

- The instructor must agree that the existing case has the potential for publication

- An individual in authority must sign a form indicating that the organization is willing to release the case subject to approval of the final version.

Assuming these prerequisites are met, the option 1 project will proceed as follows:

Key activities:

\section{PREPARATION}

- Prerequisite Verification: Groups will submit a form providing evidence of organizational approval.

- Assignment of Editing Responsibilities: Groups will indicate initial responsibility for editing each section of the case. A draft of the case will submitted with MS-Word review comments indicating responsibility for each section.

Key activities:

\section{RESPOND TO INITIAL INSTRUCTOR REVIEW}

- Instructor Review: The instructor will review the case and provide detailed comments regarding needed revisions.

- Initial Revisions: Groups will submit an edited case and a document indicating what changes were made.

Key activities:

\section{CASE SUBMIISSION}

- Submission: Groups will submit the case to the Muma Case Review once the instructor designates that it is ready.

- Final Revisions: Group will revise the case based upon peer reviews, resubmit the case and a document showing revisions. 
CHAMPAGNE, FORSYTH, MCCARTY, NUNNELEY, VANDERKOLK 
Option 2: Developing a New Case

The goal of this option is to get a new case developed by the end of the semester. While it would be desirable to have a case that is: a) approved for release by the organization, and b) submitted for publication, this is not a prerequisite. Option 2 projects will proceed as follows:

Key activities:

\section{INTRODUCTORY PAGE}

- Student groups will choose a site for the case. Ideally this will be an employer of one of the group members but that is not a requirement.

- A protagonist (decision maker) will first be identified, and then a significant decision that he or she is currently making will be selected. There is no particular constraint on the nature of the decision, beyond the fact that it is interesting and important to the protagonist.

- Submission: Collectively, the group will prepare the first page of the case (using the Muma Case Review format) and will submit it prior to the next class. Instructions on the format and on case writing will be provided on Canvas and in class.

Key activities:

\section{SECTION DEVELOPMENT}

- A typical case study is constructed of a series of sections. These vary according to the nature of the case, but generally run from the general to the specific. For example:

a. General sections (1-2 pages each): Might include a section on the industry, the technologies involved (e.g., for IT cases), the country (e.g., for international cases), the law (e.g., for cases where the regulatory environment is critical), and so forth. These sections do not need to refer to the specific organization or decision, but provide critical context.

b. Organization sections (1-2 pages each): Includes a section describing the organization (e.g., strategy, products, business model, structure) and, when necessary, a section on the specific business unit where the decision is being made.

c. Decision context section (2-3 pages): A section that describes the context and nature of the decision that needs to be made.

d. Choices section $(\sim 1$ page): A short section at the end that identifies the choices that the protagonist is considering and relevant information-such as the urgency of the decision - that focuses the reader on the specific problem that needs to be addressed.

e. Exhibit (variable): source material from the case site and/or background research that is referenced in the sections.

- Task identification: Participants on the team should each be given primary responsibility for one or more sections.

- Submission: An outline of each section should be provided, along with an indication of who has primary responsibility for the section and what additional information needs to be gathered. Instructions on the case writing process will be provided on Canvas and in class.

Key activities:

\section{FIRST DRAFT}

- Each participant will prepare a draft of his or her section.

- The group will bundle these into a case study using the Muma Case Review template.

- Submission: A first draft of the case. 
Key activities:

\section{REVISION}

- The instructor will provide detailed feedback on the first draft.

- The group will revise the case in light of the comments

- Submission: A complete and revised draft of the case, formatted using the Muma Case Review template and submitted to the MCR peer reviewing system.

\section{PEER REVIEW}

Individuals will be assigned to peer review both Option 1 and Option 2 cases.

Key activities:

- Peer reviews will be conducted using the MCR peer reviewing system

- The instructor will assign each student 1 case from another groups to peer review.

- Students will individually review the case using a form provided, providing constructive suggestions as to how it can be improved.

- Submission: 1) The individual peer review form for the assigned case prepared by each participant.

Key activities:

\section{FINAL DRAFT}

- Each group will examine the peer review comments submitted for the case that they wrote

- They will revise the case to incorporate these comments

- They will prepare a document indicating how they addressed each comment or, where appropriate, why they chose not to address a particular comment

- Submission: 1) A final version of the case, 2) the document indicating how they chose to address each comment. These will be submitted to the MCR peer reviewing system

Source: Course syllabus 


\section{Exhibit 2: "About Us" Section from Muma Case Review website}

Muma Case Review

A publication of the Muma College of Business | University of South Florida

\section{Home \\ Cases \\ Notes \\ About Us * \\ Authors * \\ Reviewers * \\ FAQS *}

\section{About Us}

ISSN 2640-6519

\section{Mission}

The Muma Case Review (MCR) is a peer reviewed journal whose mission is to publish high quality peer reviewed open access discussion cases and technicol notes.

\section{Publishing}

The MCR publishes one volume each year. Each case and technical note published receives its own number within the volume, based on the order of publication. Cases are published electronically upon acceptance.

Because faculty members generally select discussion cases individually, for a specific purpose within their curriculum, the MCR does not publish a printed volume. In conjunction with the Muma Business Press, however, it may publish printed collections of case studies from time-to-time.

\section{Support}

The operations and publications of the MCR are supported by the Muma College of Business at the University of South Florida. The journal's peer review system is maintained by the Informing Science Institute.

To contact the editorial staff, please use the journal's Contact Us page.

\section{Participation}

The journal encourages participation from authors and reviewers from around the globe. Additional information on contributing cases as an author can be found on the Authors page. Additional information on participating as a reviewer can be found on the Reviewers page.

Source: (n.d.). Retrieved April 16, 2020, from https://www.mumacasereview.org/about/ 
CHAMPAGNE, FORSYTH, MCCARTY, NUNNELEY, VANDERKOLK 


\section{Exhibit 3: "About Us” Section from Muma Case Review website}

\section{History \\ Origins}

The concept for the Muma Case Review originated in May 2015. At that time, the 25 participants in the first cohort of the Muma College of Business' new Doctor of Business Administration program had submitted one page proposals to develop discussion case studies as part of a required publication course. Upon looking over these proposals, it became clear to the college's Dean and the DBA program's Academic Director that a substantial number of publishable case studies were likely to result from these efforts (and from the efforts of subsequent cohorts). This presented a number of challenges:

1. Only a very limited number of outlets accepted discussion case submissions.

2. Very often, these outlets had length and formatting restrictions that would require substantial rewriting of cases prior to submission.

3. The peer review process of these outlets tended to be quite time consuming.

4. Once published using these outlets, cases tended to be distributed through high cost sources such as Harvard Business School Publishing.

This was a particular concern for the DBA program's academic director, who had been working on case development in many regions, such as Vietnam, South Africa and Eastern Europe, where the price of HBS cases could become a serious barrier to their use.

For this reason, the Dean and DBA Academic Director of the Muma College of Business agreed to launch a new journal specifically devoted to publishing open access discussion cases.

\section{Timeline}

\begin{tabular}{|c|c|}
\hline Year & Activity \\
\hline 2015 & $\begin{array}{l}\text { 》 June 2015: Decision to move forward with the Muma Case Review finalized. } \\
\text { » September 2015: Case discussion of the Muma Case Review and Muma } \\
\text { Business Review journals with the inaugural DBA cohort. } \\
\text { » October 2015: Part time copy editor/managing editor hired. } \\
\text { » November 2015: Journal's online architecture finalized. }\end{array}$ \\
\hline 2016 & $\begin{array}{l}\text { 》 January 2016: Journal website and peer review site launched under the } \\
\text { mumacasereview.org domain. } \\
\text { 》 February 2016: First case in Volume } 1 \text { published. } \\
\text { » December 2016: Volume } 1 \text { scheduled to close. }\end{array}$ \\
\hline
\end{tabular}

Source: (n.d.). Retrieved April 16, 2020, from https://www.mumacasereview.org/history/ 


\title{
Exhibit 4: Dr. Gill FAQ List for Prospective Case Study Participants
}

\section{Why Should I Participate in a Case Study:} Answers to 10 frequently asked questions

\author{
by \\ T. Grandon Gill \\ Professor \\ Information Systems and Decision Sciences \\ College of Business \\ University of South Florida
}

In the course of my experience in writing teaching cases, both for Harvard Business School and for Prentice Hall, I have found that managers who are considering participating start out with many questions. Here are 10 of the most common:

\section{What is a business teaching case study?}

A business teaching case study, as distinguished from a research case stuchy, is a description of an administrative situation that is specifically intended to be the basis of a class discussion. Sometimes referred to as Harvard-style cases, these cases typically have a number of distinguishing characteristics:

- Their central focus is some decision that needs to be made. While many cases (particularly research cases) have been written that document the outcome of some decision, the best teaching cases usually motivate discussion with an agenda that includes deciding what the manager needs to do.

- The situations examined tend to be complex, and multi-faceted. Just as few business decisions can be reduced to a single function, few good teaching cases attempt to present a business situation as if it were strictly a "finance" or "marketing" or "information systems" problem.

- There is rarely a single "right answer" to a case. As with all business situations, there are certainly better answers and worse answers, but good teaching cases do not come with ready-made solutions that the instructor can announce at the end of class.

In addition, as a practical matter, Harvard-style case studies tend to share a certain physical appearance: $7-12$ pages of single-spaced text followed by exhibits (figures) that may range from 1 to 15 pages.

\section{What does it cost my company to participate in a case study?}

In terms of dollars, nothing. When you participate in a case study, your firm is doing the educational community a service. Having said that, there can be a significant cost of time associated with the case writing process. 
MUMA CASE REVIEW

\section{What kind of time commitment will participating in a case involve?}

This varies from company to company, and from case-writer to case-writer. Generally, the decision-maker about whom the case revolves can expect to spend 10-20 hours in interviews, reading drafts and facilitating case writer visits, spread over the entire case writing period (usually 1-2 months). Other individuals involved in the case (5-15 is the normal number) would normally expect to spend much less time, perhaps $1-2$ hours apiece, at most, spent mainly in interviews with the case writer.

\section{How does the case writing process work?}

The case writing process normally proceeds through a series of stages:

a) Discovery: During the first phase, the case writer needs to "discover" two things: 1) the decision that will become the focus of the case and 2) the identity of the authorizing executive who will release the case (i.e., authorize for publication). Once the decision has been identified, and the authorizing executive has indicated a willingness to participate in the case-writing process, data gathering for the actual case can proceed.

b) Data Gathering: The data gathering phase usually begins with an extended (2-4 hour) interview with the decision-maker who is central to the case (a.k.a. the protagonist). After these interviews, the case writer and protagonist generally decide who should be interviewed and what background material needs to be gathered. As a practical matter, the scheduling of supporting interviews and copying of relevant documents is typically handled by the company.

c) First Draft: After the initial and supporting interviews, the case writer usually disappears for a few weeks to write the first draft of the case. Normally, in writing the first draft, the case writer identifies a) additional information that would be useful for the purposes of the case, and b) quotes that need to be authorized by individuals that have been interviewed. Requests for the former are normally forwarded to the protagonist, who determines if the information is readily available. The latter authorizations, in contrast, are normally handled by the case writer directly. Once all additional materials have been acquired and quotes have been authorized, the completed first draft of the case is delivered to the protagonist for initial comments.

d) Rewriting: As a first step, the comments of the protagonist are incorporated into any revisions. After that, the case is forwarded to the authorizing executive and/or any staff (e.g., legal, public relations) who wish to verify case content. Any requests for changes are then provided to the case writer.

e) Release: Upon receipt of an acceptable version of the case, the authorizing executive will be given a release form to sign, which states that the case writer has been granted the right to use and publish the case in its approved form. In the event a case is not released, it is viewed as sensitive company data and cannot be used in class or be published. 


\section{What if I decide I don't like the case after it has been written?}

If it has not been released, you are within your rights to tell the case writer to destroy it. If it has been released, and you have simply changed your mind, most case writers will destroy it if it is within their power to do so. If the case has already been published, however, there may be little the case writer can do. Under such unusual circumstances, however, it may be possible to rewrite or disguise the case in such a manner that it becomes satisfactory to the company.

\section{What type of access to company data will I have to give the case writer?}

In general, the case writing process goes most smoothly if you give the case writer the same type of access that you would give to any trusted outsider, such as a consultant. Always remember, as well, that just because you give the case writer a piece of sensitive information-such as a financial statement or business plan--does not mean it will necessarily appear in the case. In most instances, it is useful mainly to help the case writer understand the company situation. And, of course, should it appear in the case you can always ask to have it removed at any time before the case is released.

\section{Can I ask the case writer for his or her insights as they relate to the decision that is the subject of the case?}

Absolutely. Unlike research cases, teaching cases do not require that the writer exhibit passionless objectivity with respect to the situation being studied. For this reason, most case writers will be happy to give you their opinions on a given case situation (or on any other situation you ask them about, for that matter). Some case writers will even do what amounts to free consulting if they feel it will help them get the case released. In general, however, it is better not to mix consulting and case writing relationships while a case is in progress. At institutions like Harvard Business School, the case writing relationship in often a precursor to a consulting relationship. They generally take care, however, not to confuse the two by doing both at the same time.

\section{Who will use the case study after it has been published?}

To a great extent, this depends on how good it is and on who publishes the case study. Case studies published by places like Harvard Business School and Prentice Hall have worldwide distribution and are frequently used at 10-20 business schools. Some cases are also adopted for use in executive training sessions. Unfortunately, even experts have trouble predicting the success of a case study before it has been written and used in classes several times.

\section{Can I use the case internally, or for external relations (such as looking for investors)?}

Although case studies are normally copyrighted by the author or publisher, the case release form typically gives the company the right to make unlimited copies for its own purposes. Many companies use such cases as a convenient way to give new employees or financial partners some background on the company and its industry. 
MUMA CASE REVIEW

\section{Given the amount of company time and effort that goes into writing a case study, what are the benefits?}

There is no getting around it, participating in a case study will require a lot of work. There are, however, some benefits--mainly intangible--that often seem to accompany the case writing process. Among these:

- By allowing a case to be written about your company, you become an active participant in the educational process. While most executives complain that business schools are too divorced from the real world, those who participate in a case study can take pride in the fact that they are doing something about the problem.

- A case study can establish or reinforce relationships with the case writer and the case writer's institution. By the time a case is completed, you will have developed strong, and often enduring, relationships with the individuals who wrote the case. These relationships can prove very helpful when you find yourself looking to hire talented students or need advice on some problem that involves research.

- A case study gives you a window on how you are perceived by the outside world. Because the case writer needs to set the stage by describing the industry and the company, the case study necessarily paints a picture of your company as outsiders perceive it. In addition, should you choose to attend classes where the case is used--and you can count on being encouraged to do so!--you can often gain further insights from the way students react to your company based on the case.

- Participating in a case often helps clarify the issues associated with a particular decision. Because a case writer's main objective is to gather information relating to a particular decision, the process of deciding what factors are relevant to a decision is often more systematic than it would have been under normal circumstances. In addition, any insights, information or expertise that the case writer possesses with respect to the decision are always available to the company.

Having said all these things, this case writer's experience has been that most companies that participate in one case are eager to "come back for more". When asked why, the reason they invariably gave was that they found the case writing process to be both stimulating and enjoyable.

Source: Provided by Instructor 


\section{Exhibit 5: FL Governor Rick DeSantis Stay at Home Order}

\section{STATE OF FLORIDA OFFICE OF THE GOVERNOR EXECUTIVE ORDER NUMBER 20-51}

(Establishes COVID-19 Response Protocol and Directs Public Health Emergency)

WHEREAS, Coronavirus Disease 2019 (COVID-19) is a severe acute respiratory illness that can spread among humans through respiratory transmission and presents with symptoms similar to those of influenza; and

WHEREAS, in late 2019, a new and significant outbreak of COVID-19 emerged in China; and

WHEREAS, the World Health Organization declared COVID-19 a Public Health Emergency of Intemational Concern; and

WHEREAS, in response to the recent COVID-19 outbreak in China, Iran, Italy and South Korea, the Centers for Disease Control and Prevention ("CDC") has deemed it necessary to prohibit or restrict non-essential travel to or from those countries; and

WHEREAS, in response to the recent COVID-19 outbreak in Japan, the CDC has advised older travelers and those with chronic medical conditions to avoid nonessential travel and all travelers to exercise enhanced precautions; and

WHEREAS, the CDC currently recommends community preparedness and everyday prevention measures be taken by all individuals and families in the United States, including voluntary home isolation when individuals are sick with respiratory symptoms, covering coughs and sneezes with a tissue and disposal of the tissue immediately thereafter, washing hands often with soap and water for at least 20 seconds, use of alcohol-based hand sanitizers with $60 \%-95 \%$ 


\section{Exhibit 5 (cont.): FL Governor Rick DeSantis Stay at Home Order}

alcohol if soap and water are not readily available and routinely eleaning frequently touched surfaces and objects to increase community resilience and readiness for responding to an outbreak; and

WHEREAS, two individuals in the State of Florida tested presumptively positive for COVID-19, including a resident of Manatee County and a resident of Hillsborough County; and

WHEREAS, the CDC currently recommends mitigation measures in communities with COVID-19 cases, including staying at home when sick, keeping away from others who are sick and staying at home when a household member is sick with respiratory disease symptoms or if instructed to do so by public health officials or a health care provider; and

WHEREAS, it is necessary and appropriate to take action to ensure that COVID-19 remains controlled and that residents and visitors in Florida remain safe and secure;

NOW, THEREFORE, I, RON DESANTIS, as Governor of Florida, by virtue of the authority vested in me by Article IV, Section (1)(a) of the Florida Constitution, and all other applicable laws, promulgate the following Executive Order to take immediate effect:

Section 1. Because of the foregoing conditions, I direct the State Health Officer and Surgeon General, Dr. Scott Rivkees, to declare a public health emergency in the State of Florida, pursuant to his authority in section 381.00315 , Florida Statutes. The State Health Officer is authorized and directed to use his judgment as to the duration of this public health emergency.

Section 2. In accordance with section 381.0011(7), Florida Statutes, 1 direct the State Health Officer to take any action necessary to protect the public health.

Section 3. I direct the State Health Officer to follow the guidelines established by the CDC in establishing protocols to control the spread of COVID-19 and educate the public on prevention. 


\section{Exhibit 5 (cont.): FL Governor Rick DeSantis Stay at Home Order}

Section 4. In accordance with section 381.0011(7), Florida Statutes, I designate the Florida Department of Health as the lead state agency to coordinate emergency response activities among the various state agencies and local governments. The State Health Officer, or his designee, shall advise the Executive Office of the Governor on the implementation of these emergency response activities.

Section 5. All actions taken by the State Health Officer with respect to this emergency before the issuance of this Executive Order are ratified.

Section 6. The Florida Department of Health will actively monitor, at a minimum, all persons meeting the definition of a Person Under Investigation ("PUT") as defined by the CDC for COVID-19 for a period of at least 14 days or until the PUI tests negative for COVID-19. Active monitoring by the Florida Department of Health will include at least the following:

A. Risk assessment within 24 hours of learning an individual meets the criteria for a PUI.

B. Twice-daily temperature checks.

Section 7. The Florida Department of Health, pursuant to its authority in section 381.00315, Florida Statutes, will ensure that all individuals meeting the CDC's definition of a PUI are isolated or quarantined for a period of 14 days or until the person tests negative for COVID19.

Section 8 . I hereby direct the Florida Department of Health to make its own determinations as to quarantine, isolation and other necessary public health interventions as permitted under Florida law.

Section 9. I direct all agencies under the direction of the Governor to fully cooperate with the Florida Department of Health, and any representative thereof in furtherance of this Order. 
Agencies not under the direction of the Governor are requested to provide such assistance as is required.

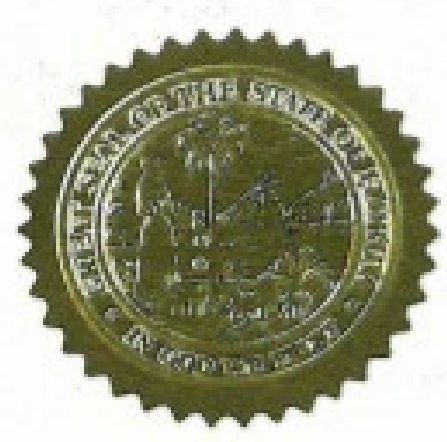

IN TESTIMONY WHEREOF, I have hereunto set my hand and caused the Great Seal of the State of Florida to be affixed, at Tallahassee, this Ist day of March, 2020.

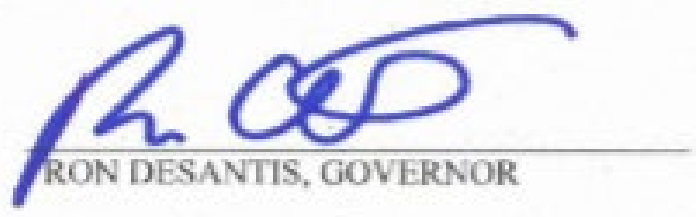

ATTEST:

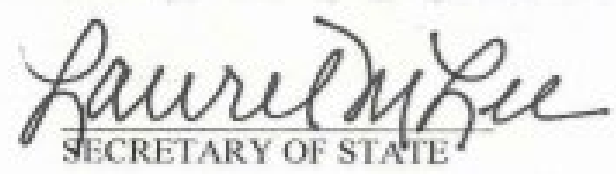

Source: DeSantis, R. (2020, March 1). [PDF]. State of Florida. 


\section{Exhibit 6: Coronavirus Impact to Economy Infographics}

More than $30 \mathrm{~m}$ people in the US have filed for unemployment benefits in last six weeks

Weekly total of new unemployment claims in 2020

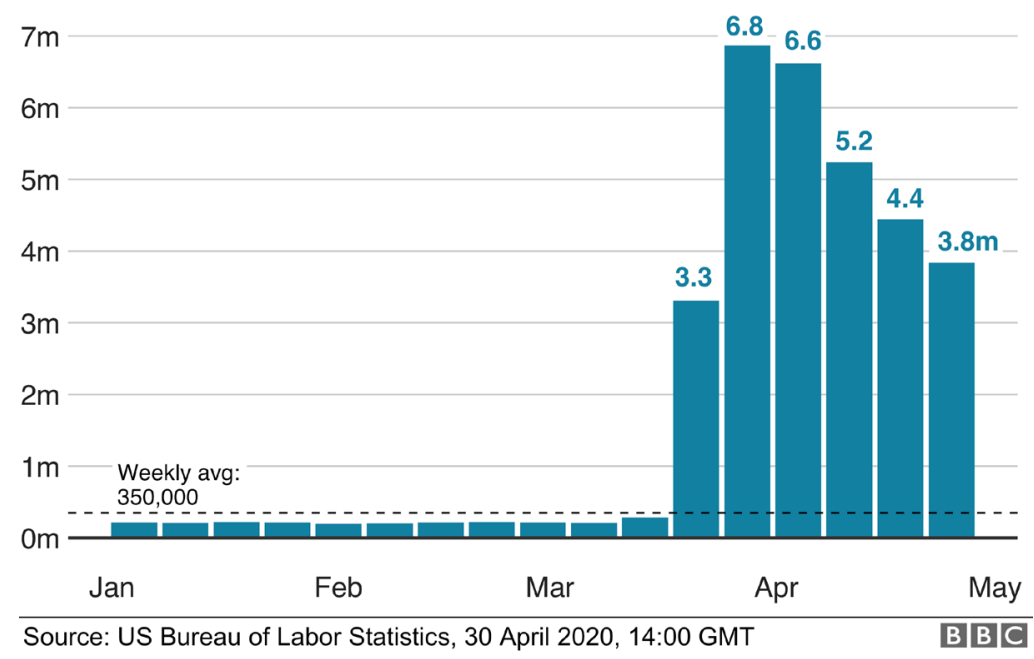

Chinese industrial production fell further in March

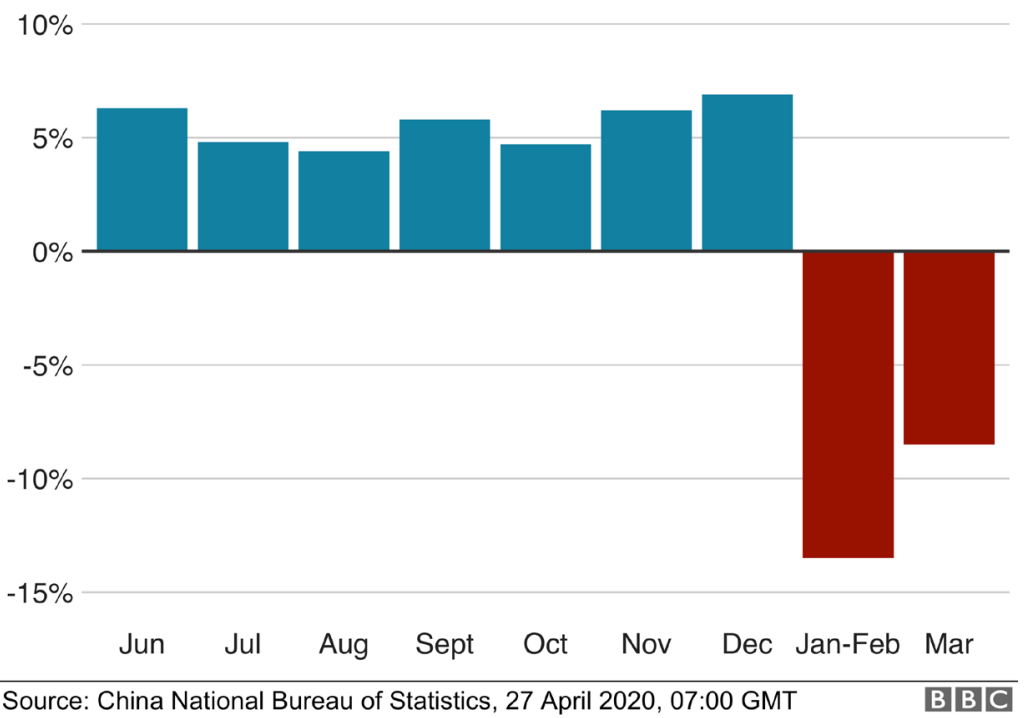

Source: China National Bureau of Statistics, 27 April 2020, 07:00 GMT $\quad$ B BC 
The impact of coronavirus on stock markets since the start of the outbreak

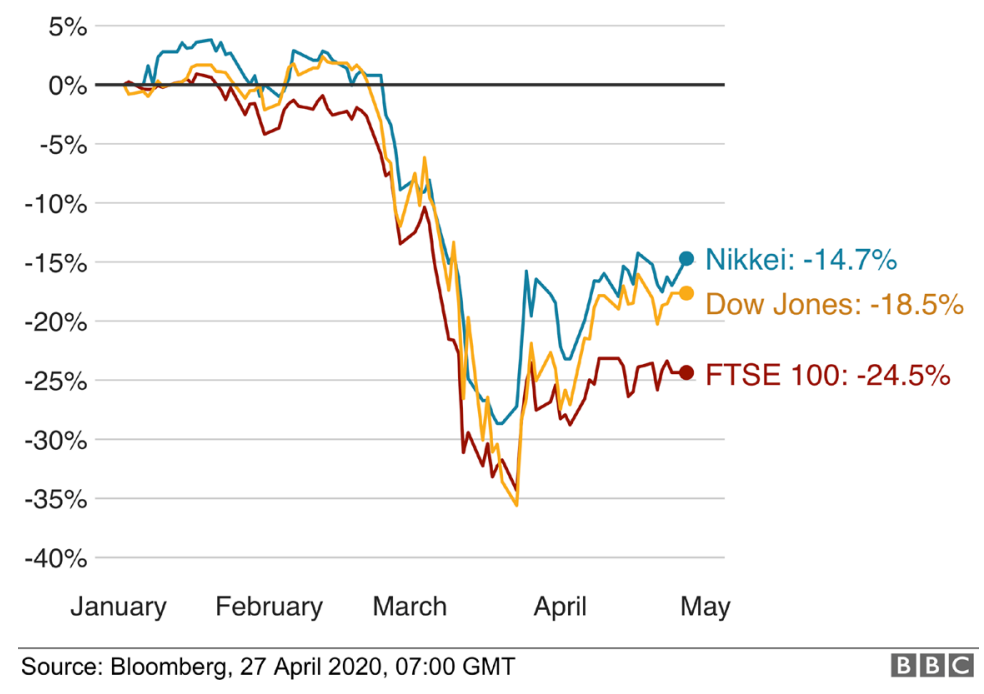

\section{Many advanced economies are expected to enter recession this year}

National annual GDP
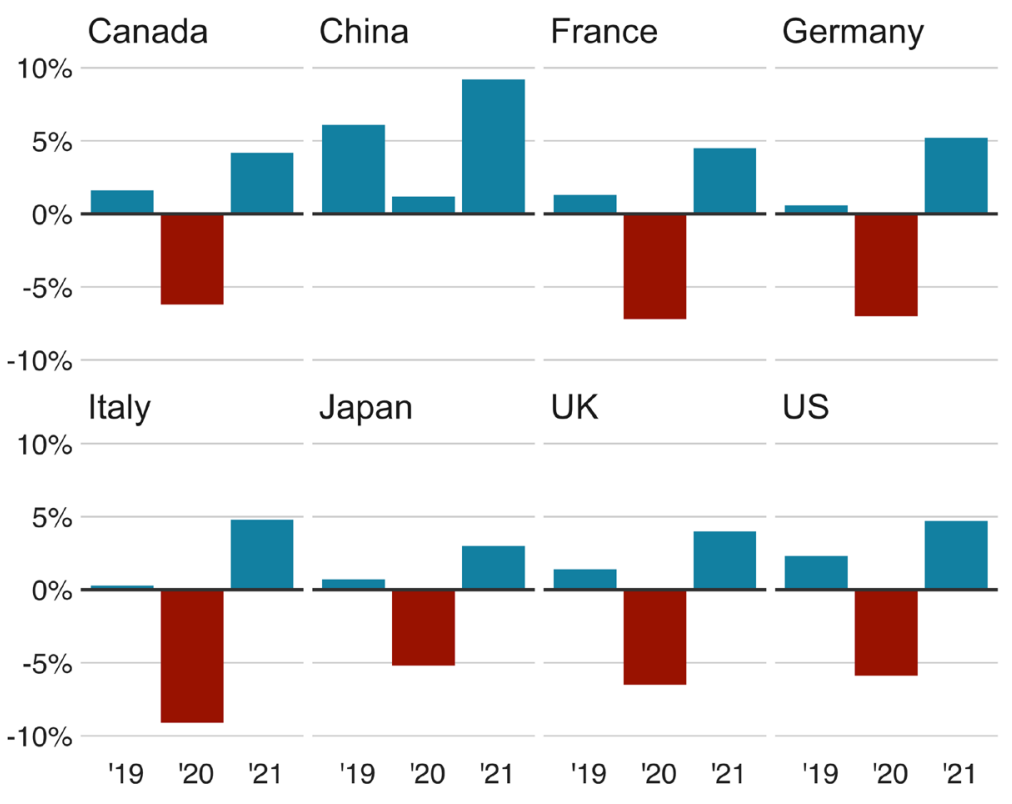

Source: International Monetary Fund $\quad$ B B C

Source: Palumbo, D. (2020, April 30). Coronavirus: A visual guide to the economic impact. Retrieved May 3, 2020, from https://www.bbc.com/news/amp/business-51706225 